Article

\title{
An Improved System for Utilizing Low-Temperature Waste Heat of Flue Gas from Coal-Fired Power Plants
}

\author{
Shengwei Huang, Chengzhou Li (D), Tianyu Tan, Peng Fu, Gang Xu and Yongping Yang * \\ National Thermal Power Engineering \& Technology Research Center, North China Electric Power University, \\ Beijing 102206, China; china_hsw@163.com (S.H.); chengzhou_li@163.com (C.L.); tantianyu1229@126.com (T.T.); \\ paulfp235@126.com (P.F.); xugang@ncepu.edu.cn (G.X.) \\ * Correspondence: yyp@ncepu.edu.cn; Tel.: +86-10-6177-2000
}

Received: 10 July 2017; Accepted: 15 August 2017; Published: 19 August 2017

\begin{abstract}
In this paper, an improved system to efficiently utilize the low-temperature waste heat from the flue gas of coal-fired power plants is proposed based on heat cascade theory. The essence of the proposed system is that the waste heat of exhausted flue gas is not only used to preheat air for assisting coal combustion as usual but also to heat up feedwater and for low-pressure steam extraction. Air preheating is performed by both the exhaust flue gas in the boiler island and the low-pressure steam extraction in the turbine island; thereby part of the flue gas heat originally exchanged in the air preheater can be saved and introduced to heat the feedwater and the high-temperature condensed water. Consequently, part of the high-pressure steam is saved for further expansion in the steam turbine, which results in additional net power output. Based on the design data of a typical $1000 \mathrm{MW}$ ultra-supercritical coal-fired power plant in China, an in-depth analysis of the energy-saving characteristics of the improved waste heat utilization system (WHUS) and the conventional WHUS is conducted. When the improved WHUS is adopted in a typical $1000 \mathrm{MW}$ unit, net power output increases by $19.51 \mathrm{MW}$, exergy efficiency improves to $45.46 \%$, and net annual revenue reaches USD 4.741 million while for the conventional WHUS, these performance parameters are $5.83 \mathrm{MW}, 44.80 \%$ and USD 1.244 million, respectively. The research described in this paper provides a feasible energy-saving option for coal-fired power plants.
\end{abstract}

Keywords: coal-fired power plants; waste heat utilization; thermodynamic analysis; exergy analysis; techno-economic analysis

\section{Introduction}

Power generation in China depends highly on coal-fired power plants, which contribute around $70 \%$ of the total installed power capacity ( 1.25 billion $\mathrm{kW}$ at the end of 2013 ) and approximately $78 \%$ of the total electricity generation (5.25 trillion $\mathrm{kWh}$ ) [1,2]. More importantly, the generation capacity continues to increase with an annual increment of 30-50 million $\mathrm{kW}$ [1]. Therefore, coal-fired power plants continue to dominate power generation in China, and will do so in the long term [3,4]. However, since coal power generation is energy intensive and with high pollutant emission [5-7], it makes sense, particularly with increasing fuel prices and strict energy-saving environment protection policy, to further reduce fuel consumption which could simultaneously reduce pollutant emissions, for the same amount of power generated [6].

In addition to the traditional measures used to improve the performance of the steam cycle design [8-10], e.g., employing more feedwater preheaters or reheaters [11-16] and applying optimal steam cycle design $[11,17,18]$, another effective way which has been widely discussed in recent years $[19,20]$, is the in-depth utilization of low-temperature waste heat from the exhausted flue gas. To achieve this, low-temperature economizers (LTEs) are usually configured after or parallel to the air preheater to recover the waste heat from the flue gas to heat up a part of the condensate water [21,22]. 
From the viewpoint of thermodynamics, this measure can directly suppress the utilization of steam extraction for feedwater preheating, thus allowing more steam to expand throughout the whole turbine and to generate more power. Consequently, the net efficiency of the whole plant can be improved.

So far, the academic research on efficient utilization of flue-gas waste heat mainly concentrates on novel layouts of the recovery system and special heat exchangers to meet the demanding conditions of flue gas from coal combustion. For example, Espatolero et al. [23] explored the effects of the temperature of exhausted flue gas and the heat-exchanger performance on waste heat recovery, and evaluated the energy-saving effect for the boiler cold-end. Chen et al. [24] investigated several new technologies to exploit low-grade heat recovery from humid flue gas, taking the latent heat of water vapor condensation into account. Xu et al. $[25,26]$ proposed a novel waste heat recovery system by dividing the air preheater into high-temperature and low-temperature preheaters. An additional low-temperature economizer is placed between the electrostatic precipitator and the low-temperature air preheater. This proposal achieves a net additional power output of $9 \mathrm{MW}$ for a $1000 \mathrm{MW}$ coal-fired power plant. Wang et al. [27] developed an advanced waste heat and water recovery technology using nanoporous ceramic membrane to extract a portion of the water vapor and its latent heat from flue gases.

For industrial applications of flue-gas waste heat recovery, several projects have been launched or are currently ongoing. For example, the German Schwarze Pumpe power plant $(2 \times 800 \mathrm{MW}$ lignite generation units) implemented a flue gas division system after the electrostatic precipitator and recovered low-grade heat to heat up the condensed feedwater. Significant energy-saving effects have been reported [28,29]. In China, several $1000 \mathrm{MW}$ scale coal-fired power plants, including the most efficient coal-fired power plant in the world (Waigaoqiao No. 3 power plant in Shanghai) [30], have adopted the waste heat utilization system (WHUS) to heat up the condensed water. The employed low-temperature economizer promotes the boiler efficiency by 2 percentage points and the net plant efficiency by 0.8 to 0.9 percentage point [31-33].

There are two major issues to be addressed for low-grade heat recovery from flue gas: (1) Most of the proposed concepts depend on a low-temperature economizer which mostly work near or even below the acid dew point, causing severe material corrosion; (2) The temperature of exhaust flue gas has been rather low and the small temperature difference of the heat transfer leads to a large heat exchanger area and high investment costs. Thus, in-depth research of the waste heat utilization is of great importance to find the best trade-off design between efficiency improvement and the capital investment.

With the above context and following our previous research on low-grade waste heat for power plants, we propose a novel waste heat recovery system and improve the original system based on a comprehensive understanding of the performance relevance between the air preheating process in the boiler island and the feedwater preheating process in the turbine island. Cascade utilization of heat is realized between different working fluids (flue gas, steam extraction, air, etc.). The paper is organized as follows: In Section 2, the basic concept of waste heat recovery and its evaluation criteria are introduced. Then, in Section 3, the conventional heat recovery system is analyzed to highlight the existing bottleneck for in-depth utilization of potential waste heat. Subsequently, in Section 4, we propose an improved WHUS system and evaluate the system by both thermodynamic and economic criteria. Finally, the conclusions are drawn (Section 5).

\section{Waste Heat Recovery and the Evaluation Criteria}

The basic concept for recovering waste heat from exhausted flue gas to heat up the low-temperature feedwater is illustrated in Figure 1. With the recovered heat, the requirement of steam extraction for heating up feedwater preheater is reduced, thus more steam can expand fully to the condensate pressure for additional power generation. 


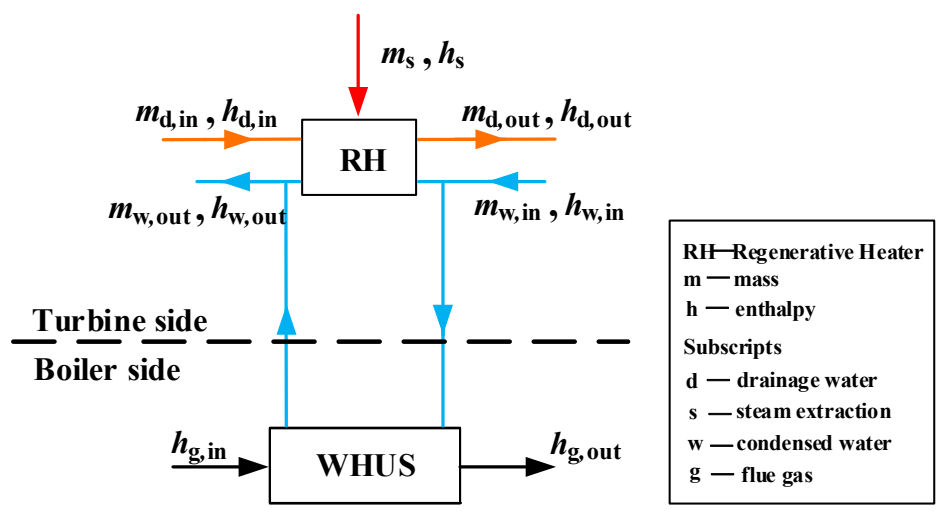

Figure 1. Schematic of the waste heat utilization system (WHUS).

\subsection{Thermodynamics of Waste Heat Recovery}

The amount of heat recovered from the exhausted flue gas is calculated as follows:

$$
\dot{Q_{1}}=m_{\mathrm{g}}\left(h_{\mathrm{g}, \text { in }}-h_{\mathrm{g}, \text { out }}\right)
$$

where $m_{\mathrm{g}}$ is the mass flow rate of the flue gas $(\mathrm{kg} / \mathrm{s}) ; h_{\mathrm{g}, \text { in }}$ and $h_{\mathrm{g}, \text { out }}$ refer to the input and output enthalpy of the flue gas, respectively $(\mathrm{kJ} / \mathrm{kg})$. Note that the enthalpy change in Equation (1) has already taken latent heat of water condensation into account.

Energy balance of a feedwater preheater can be expressed by Equation (2), if no external heat is introduced to the considered feedwater preheater:

$$
\left(m_{\mathrm{w}, \text { out }} h_{\mathrm{w}, \text { out }}-m_{\mathrm{w}, \text { in }} h_{\mathrm{w}, \text { in }}\right)=m_{\mathrm{s}} h_{\mathrm{s}}+m_{\mathrm{d}, \text { in }} h_{\mathrm{d}, \text { in }}-m_{\mathrm{d}, \text { out }} h_{\mathrm{d}, \text { out }}
$$

If certain heat recovered is utilized in the feedwater preheater, the heat balance in Equation (2) then becomes:

$$
\left(m_{\mathrm{w}, \text { out }}^{\prime} h_{\mathrm{w}, \text { out }}^{\prime}-m_{\mathrm{w}, \text { in }}^{\prime} h_{\mathrm{w}, \text { in }}^{\prime}\right)=m_{\mathrm{s}}^{\prime} h_{\mathrm{s}}^{\prime}+m_{\mathrm{d}, \text { in }}^{\prime} h_{\mathrm{d}, \text { in }}^{\prime}+\dot{Q}_{1}-m_{\mathrm{d}, \text { out }}^{\prime} h_{\mathrm{d}, \text { out }}^{\prime}
$$

where $m, h$, and $\dot{Q}_{1}$ are the mass, enthalpy, and the heat recovered from the flue gas, respectively.

We assume that the power plant under consideration operates at steady state with or without the heat recovery system and we consider only the system design with no partial-load operation. Thus, the following equations are established: $m_{\mathrm{w}, \text { out }}=m_{\mathrm{w}, \text { out }}^{\prime}, h_{\mathrm{w}, \text { out }}=h_{\mathrm{w}, \text { out }}^{\prime}, m_{\mathrm{d}, \text { in }}=m_{\mathrm{d}, \text { in }}^{\prime}, h_{\mathrm{d} \text {, in }}=h_{\mathrm{d}, \text { in }}^{\prime}$, $h_{\mathrm{s}}=h_{\mathrm{s}}^{\prime}, m_{\mathrm{w}, \text { out }}^{\prime}=m_{\mathrm{w}, \text { in }}^{\prime}+m_{\mathrm{s}}^{\prime}, m_{\mathrm{w}, \text { out }}=m_{\mathrm{w}, \text { in }}+m_{\mathrm{s}}, m_{\mathrm{d}, \text { out }}^{\prime}=m_{\mathrm{d}, \text { in }}^{\prime}+m_{\mathrm{s}}^{\prime}$, and $m_{\mathrm{d}, \text { out }}=m_{\mathrm{d}, \text { in }}+m_{\mathrm{s}}$. Thus, the amount of steam extraction suppressed by introducing waste heat for the feedwater preheater, $\Delta m$, can be formulated as below [22]:

$$
\Delta m=m_{\mathrm{s}}-m_{\mathrm{s}}^{\prime}
$$

\subsection{Additional Work}

The additional work generated by the expansion of the extra stream can be calculated as:

$$
\Delta P=\frac{\Delta m \cdot\left(h_{\mathrm{s}}-h_{0}\right)}{1000}
$$

where $h_{\mathrm{s}}$ and $h_{0}$ stand for the enthalpy of the steam extraction and the exhaust steam, respectively $(\mathrm{kJ} / \mathrm{kg}), \Delta m$ is the mass flow rate of the suppressed steam extraction $(\mathrm{kg} / \mathrm{s})$, and the $\Delta P$ is additional work (MW).

Taking the change of power consumption of the auxiliary devices, $\Delta P_{\mathrm{f}}$, into account, the net additional power output of the whole power plant can be expressed as follows: 


$$
\Delta P_{\text {net }}=\Delta P-\Delta P_{\mathrm{f}}
$$

The increment of auxiliary power consumption is mainly due to the induced draft fans configured in the boiler rear flue gas duct to compensate the pressure loss of flue gas when flowing through the additional heat exchangers for heat recovery. The increase in the fan power can be calculated as follows:

$$
\Delta P_{\mathrm{f}}=\frac{D \cdot \Delta P_{\mathrm{r}}}{1000 \eta_{\mathrm{f}}}
$$

where $\Delta P_{\mathrm{r}}$ is the increase in the pressure drop of exhausted flue gas $(\mathrm{kPa}), \eta_{\mathrm{f}}$ is the isentropic efficiency of the induced draft fan $\left(\eta_{\mathrm{f}}=0.85\right)[26,34]$ and $D$ is the volumetric flow rate of the flue gas $\left(\mathrm{m}^{3} / \mathrm{s}\right)$.

\subsection{Heat Rate Reduction}

The power industry usually uses the heat rate as a common indicator to evaluate the performance of a power generation unit. The heat rate $q$ represents the amount of fuel energy input per $1 \mathrm{kWh}$ net electricity output. Given the net additional power generation $\Delta P_{\text {net }}$, the reduction in the plant heat rate is thus represented by Equation (8) [35]:

$$
\Delta q=3600 E_{\text {total }}\left[\frac{1}{P_{\text {net }}}-\frac{1}{P_{\text {net }}+\Delta P_{\text {net }}}\right]
$$

where the $E_{\text {total }}$ refers to the total input energy (MW), while the $P_{\text {net }}$ is the net electricity output (MW), the $\Delta q$ is the reduction plant heat rate $(\mathrm{kJ} / \mathrm{kWh})$.

\section{Description of Conventional Waste Heat Utilization Systems}

\subsection{Reference Coal-Fired Power Generation Unit}

In this paper, we selected a typical $1000 \mathrm{MW}$ ultra-supercritical power generation unit in China as a case study to quantify the benefit from the waste heat recovery from flue gas. The net power output of the selected power plant is $942 \mathrm{MW}$ with a pressure of main steam of $26.25 \mathrm{MPa}$, and a temperature of main and reheated steam of $600{ }^{\circ} \mathrm{C}$. The plant is designed for a bituminous coal with an element analysis of $56.26 \%$ carbon, $3.79 \%$ hydrogen, $12.11 \%$ oxygen, $0.82 \%$ nitrogen, $0.17 \%$ sulfur and $18.1 \%$ water. The layout of the power plant has been given in Figure 2 and the stream data of all regenerative heaters (RHs), when the heat recovery system is not considered, is listed in Table 1 for the operating condition THA (the turbine heat rate acceptance condition). Under the THA condition, the inlet parameters and the back pressure are rated with the regenerative system operating normally, thus rated power is generated steadily. More detailed descriptions of large-scale (1000 MW level) coal-fired power plants can be found in $[7,8,11,12]$ and will not be repeated here. The simulation of the power plants is performed by a professional simulator, Ebsilon Professional, as also employed in these studies $[7,8,11,12]$.

Table 1. Major stream data relevant to all feedwater preheaters under the turbine heat rate acceptance (THA) condition.

\begin{tabular}{cccccccccc}
\hline Item & Unit & RH1 & RH2 & RH3 & DEA & RH5 & RH6 & RH7 & RH8 \\
\hline Temperature of steam extraction & ${ }^{\circ} \mathrm{C}$ & 393.0 & 351.2 & 482.6 & 380.5 & 288.6 & 192.1 & 86.1 & 63.6 \\
Pressure of steam extraction & $\mathrm{MPa}$ & 7.26 & 5.39 & 2.29 & 1.11 & 0.56 & 0.23 & 0.06 & 0.02 \\
Temperature of outgoing feedwater & ${ }^{\circ} \mathrm{C}$ & 290.0 & 268.7 & 219.4 & 183.8 & 153.3 & 122.1 & 83.3 & 60.8 \\
Pressure of outgoing feedwater & $\mathrm{MPa}$ & 32.70 & 32.80 & 32.90 & 1.09 & 1.29 & 1.34 & 1.39 & 1.44 \\
Temperature of incoming feedwater & ${ }^{\circ} \mathrm{C}$ & 268.7 & 219.4 & 189.9 & 153.3 & 122.1 & 83.3 & 60.8 & 36.2 \\
Pressure of the incoming feedwater & $\mathrm{MPa}$ & 32.80 & 32.90 & 33.00 & 1.29 & 1.34 & 1.39 & 1.44 & 1.53 \\
Temperature of the drainage & ${ }^{\circ} \mathrm{C}$ & 274.3 & 225.0 & 195.5 & - & 127.6 & 124.6 & 86.1 & 63.6 \\
\hline
\end{tabular}




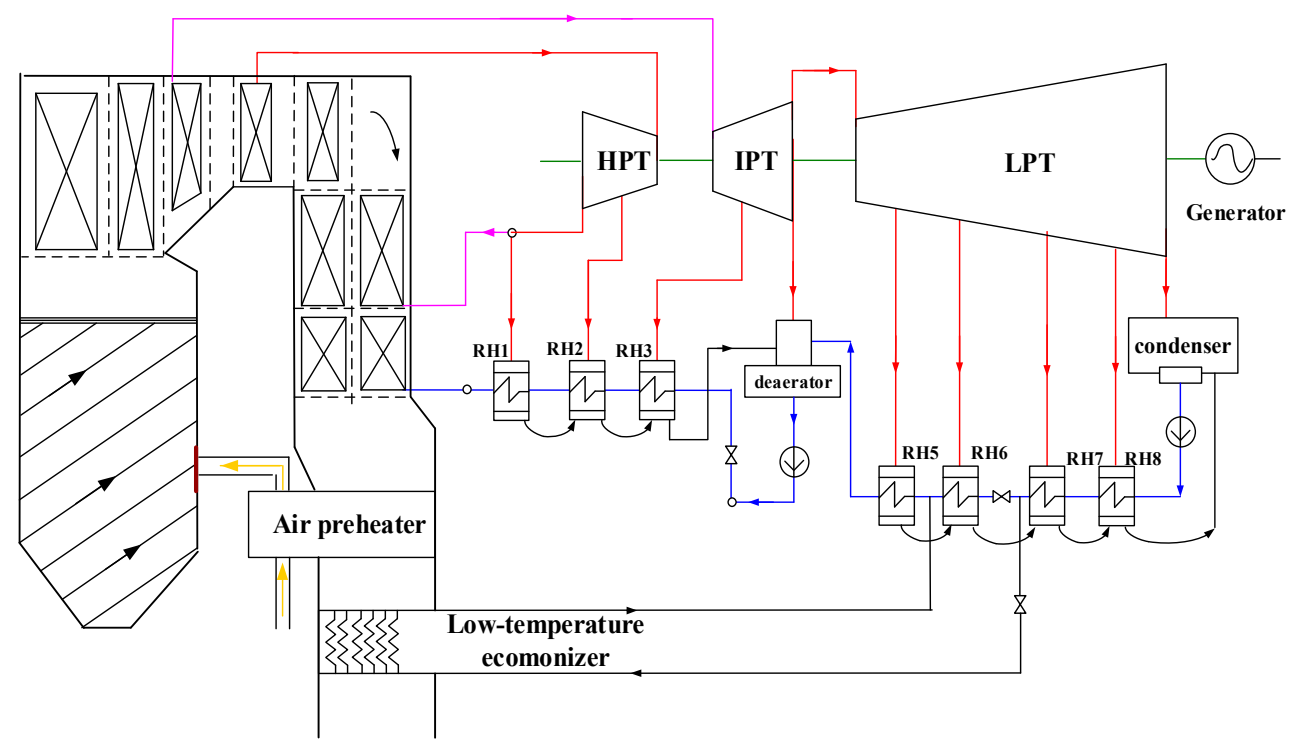

Figure 2. Schematic of the considered coal-fired power plant with a conventional heat recovery system.

\subsection{Conventional Waste Heat Recovery System}

In the coal-fired power plant being considered, a large amount of steam with different parameters needs to be extracted to heat the feedwater and the condensed water, that is, the regenerative process. In this process, the temperatures of the feedwater and condensed water will be increased, which improves the thermodynamic cycle efficiency. However, the working ability of the steam, which is extracted from the turbine to heat the feedwater and the condensed water, will be destroyed since it can no longer continue to expand in the steam turbine. In the conventional WHUS, the exhaust energy of the flue gas is utilized to heat the condensed water; part of the steam extraction is thus saved and can continue to expand for more power output. As a result, it raises the gross power output and improves the thermal conversion efficiency.

Figure 2 depicts the configuration of the conventional WHUS. The LTE is arranged downstream of the air preheater in the flue gas duct, which is parallel to the RH6. Part of the condensed water at the inlet of the RH6 will enter the LTE and return to the regenerative system after absorbing the flue gas waste heat. Then, the condensed water will converge with the main condensed water at the outlet of the RH6. In this way, the sixth-stage steam extraction can be partly saved.

Table 2 presents the thermodynamic analysis results of the conventional WHUS. The inlet flue gas temperature of the LTE is equal to that of the exhaust flue gas from the air preheater, which is $131^{\circ} \mathrm{C}$. Meanwhile, the acid dew point $\left(t_{\mathrm{adp}},{ }^{\circ} \mathrm{C}\right)$ can be calculated as follows [36]:

$$
t_{\mathrm{adp}}=t_{\mathrm{wdp}}+\frac{\beta \cdot\left(S_{\mathrm{ar}, \mathrm{zs}}\right)^{1 / 3}}{1.05^{\left(\alpha_{\mathrm{ash}} \cdot A_{\mathrm{ar}, \mathrm{ss}}\right)}}
$$

where $t_{\mathrm{wdp}}$ is the dew point temperature of water with the corresponding water vapor pressure of the flue gas $\left({ }^{\circ} \mathrm{C}\right), \beta$ is the coefficient related to the excess air coefficient $(\beta=121)$ [37], $S_{\mathrm{ar}, z \mathrm{~s}}$ and $A_{\mathrm{ar}, \mathrm{zs}}$ are the sulfur and ash content at as-received basis $(\mathrm{kg} / \mathrm{kcal})$, and finally the $\alpha_{\text {ash }}$ is the fly-ash share in the fuel gas (0.9) [37].

Due to the relatively low sulfur content of the coal (approximately $0.17 \%$ ), the temperature of the acid dew point is $92.2^{\circ} \mathrm{C}$; as well as the acid steam wraparound effect brought by the flying ash, the outlet flue gas temperature of the LTE can be reduced to $100{ }^{\circ} \mathrm{C}$ without serious corrosion problem. According to thermodynamics, the smaller the temperature difference between the working mediums, the smaller heat transfer exergy destruction. In this case, higher condensed water temperature is preferred, given the fixed flue gas temperature range. In related heat transfer and techno-economic 
theories, however, a small heat transfer temperature difference increases the heat transfer area and the volume of the heat exchange device. As a result, investment in the heat exchanger is increased. To balance the thermodynamic performance and equipment investment in the conventional WHUS, the LTE adopts the counter-current arrangement and is connected in parallel to RH6. By using this arrangement, on the one hand-provided that the engineering constraint is allowed-the condensed water temperature is enhanced as high as possible. As seen in Table 2, considering the flue gas temperature of the LTE is only $131-100{ }^{\circ} \mathrm{C}$, which can only be used to heat the condensed water of RH6 at most $\left(83.3-122.1^{\circ} \mathrm{C}\right)$. On the other hand, the outlet condensed water temperature of the LTE is set to $116^{\circ} \mathrm{C}$, slightly lower than $122.1^{\circ} \mathrm{C}$, which ensures the minimum heat transfer temperature difference of the LTE is maintained over $15^{\circ} \mathrm{C}$ [21]. Overall, the total investment cost of the conventional WHUS can be maintained at a relatively acceptable level. Meanwhile, the net power output is increased by $5.83 \mathrm{MW}$, whereas the heat rate of the generation unit is reduced by $42.56 \mathrm{~kJ} / \mathrm{kWh}$.

Table 2. Thermodynamic analysis of the conventional WHUS.

\begin{tabular}{ccc}
\hline Item & Unit & Conventional WHUS \\
\hline Inlet flue gas temperature & ${ }^{\circ} \mathrm{C}$ & 131 \\
Outlet flue gas temperature & ${ }^{\circ} \mathrm{C}$ & 100 \\
Inlet condensed water temperature & ${ }^{\circ} \mathrm{C}$ & 83.3 \\
Outlet condensed water temperature & ${ }^{\circ} \mathrm{C}$ & 116 \\
Additional auxiliary power consumption & $\mathrm{MW}$ & 1.25 \\
Gross work output & $\mathrm{MW}$ & 1007.15 \\
Additional gross work output & $\mathrm{MW}$ & 7.15 \\
Net work output & $\mathrm{MW}$ & 947.83 \\
Additional net work output & $\mathrm{MW}$ & 5.83 \\
Reduction of heat rate & $\mathrm{kJ} / \mathrm{kWh}$ & 42.56 \\
\hline
\end{tabular}

In the LTE, the energy donor is the exhaust flue gas and the energy acceptor is the condensed water of the regenerative system. Therefore, WHUS performance is affected not only by the characteristic of the flue gas, but also by the parameters of the steam cycle. Specifically, power output and economic benefits are not only affected by the quantities of heat released by the flue gas, but also by the parameters of saved steam extraction. In the conventional WHUS, the LTE is installed in the outlet of the air preheater, the inlet flue gas temperature of the LTE is only $131{ }^{\circ} \mathrm{C}$, which can replace the sixth-stage steam extraction at most, as shown in Figure 3. The sixth-stage steam extraction is characterized by a relatively low working ability since its pressure is only $0.23 \mathrm{MPa}$, which is the limiting factor for improving the energy-saving effects of recycling the flue gas waste heat.

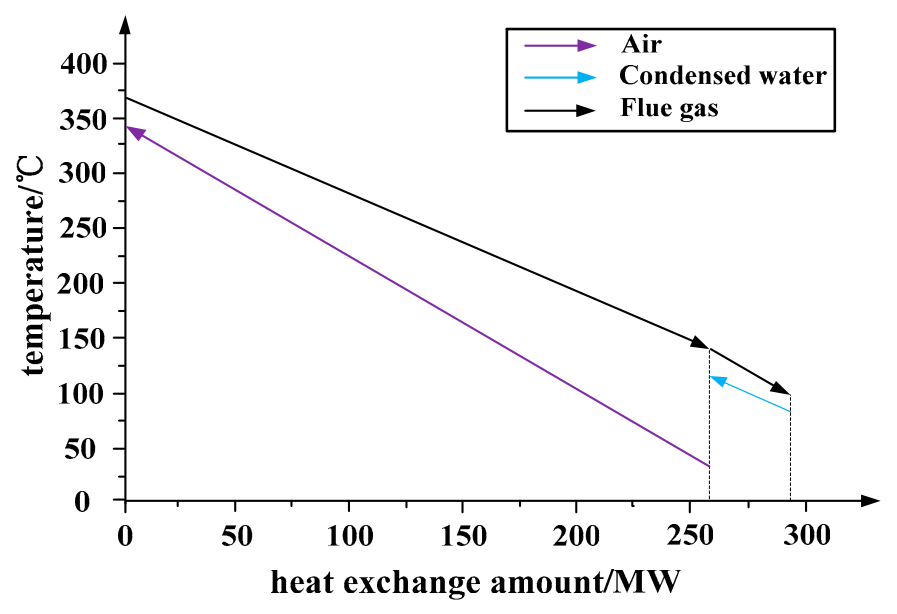

Figure 3. Heat transfer curve of the conventional WHUS. 


\section{Proposal and Performance Analysis of the Improved WHUS}

\subsection{Description of the Improved WHUS}

According to the analysis above, to further improve the energy conservation effects of the WHUS, it is essential to enhance the flue gas temperature that is entering the LTE. Meanwhile, note that the logarithmic mean temperature difference of the air preheating process is relatively large (over $60^{\circ} \mathrm{C}$ ). Thus, to utilize the energy rationally, an improved WHUS is proposed in this section.

Figure 4 illustrates the improved WHUS. This system adds a bypass flue gas duct which is paralleled with the main air preheater. In the bypass flue gas duct, two gas-water heat exchangers are successively installed, approximately one-third of the outlet flue gas of the economizer enters the high-temperature gas-water heat exchanger and the low-temperature gas-water heat exchanger of the bypass flue gas duct in sequence, to heat the feedwater $\left(189.9-290^{\circ} \mathrm{C}\right)$ and the condensed water $\left(83.3-153.3^{\circ} \mathrm{C}\right)$, respectively. Since the heat of the flue gas entering the main air preheater reduces in the improved WHUS, two additional heat exchangers are added to maintain the inlet air temperature of the furnace. Among them, the first-stage heat exchanger utilizes the low-pressure steam extraction to heat the air, while the second one applies the waste flue gas $\left(131-100^{\circ} \mathrm{C}\right)$ to heat the air. The parameters of the main heat exchange equipment are shown in Table 3.

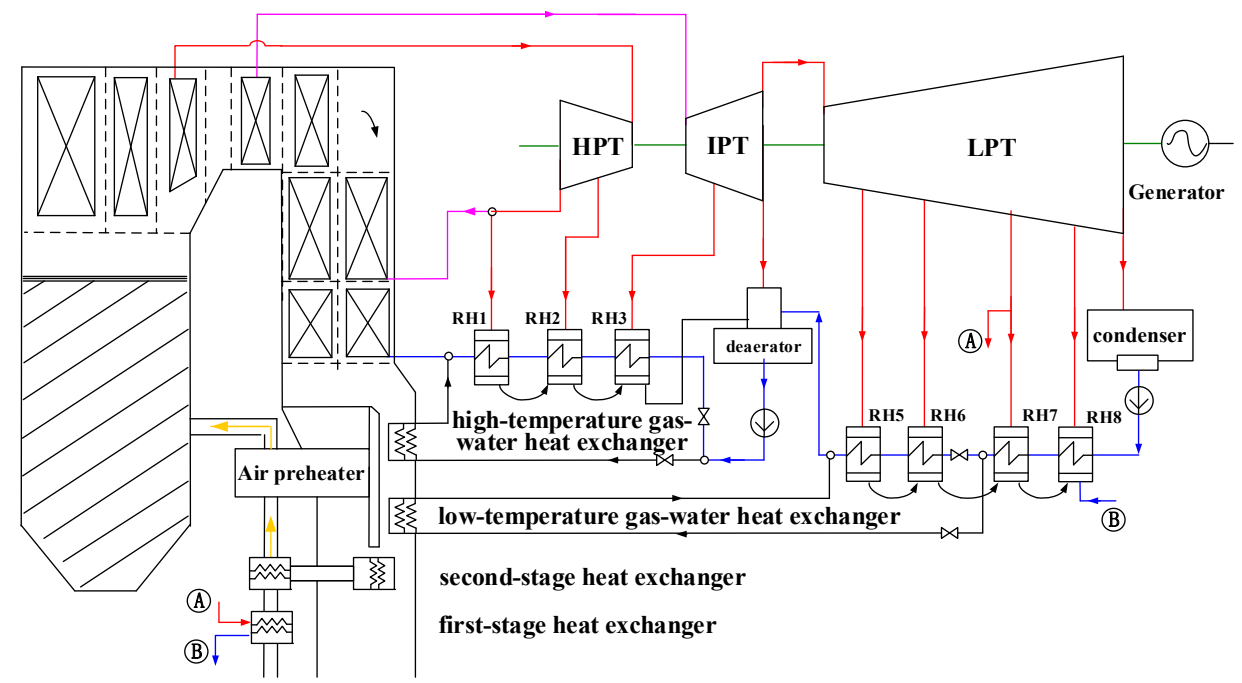

Figure 4. Schematic of the thermal system of a power plant with the improved WHUS.

Table 3. Parameters for the main heat exchangers.

\begin{tabular}{cccccc}
\hline Item & Unit & $\begin{array}{c}\text { High-temperature } \\
\text { Gas-water Heat } \\
\text { Exchanger }\end{array}$ & $\begin{array}{c}\text { Low-temperature } \\
\text { Gas-water Heat } \\
\text { Exchanger }\end{array}$ & $\begin{array}{c}\text { First-stage } \\
\text { Heat } \\
\text { Exchanger }\end{array}$ & $\begin{array}{c}\text { Second-stage } \\
\text { Heat } \\
\text { Exchanger }\end{array}$ \\
\hline Inlet flue gas & ${ }^{\circ} \mathrm{C}$ & 372 & 204.8 & - & 131 \\
\hline Outlet flue gas & ${ }^{\circ} \mathrm{C}$ & 204.8 & 131 & - & 100 \\
\hline Inlet water/steam & ${ }^{\circ} \mathrm{C}$ & 189.8 & 83.3 & $86.1\left(1^{*}\right)$ & - \\
\hline Outlet water/steam & ${ }^{\circ} \mathrm{C}$ & 290 & 153.3 & $86.1\left(0^{*}\right)$ & - \\
\hline Inlet air & ${ }^{\circ} \mathrm{C}$ & - & - & 60 & 100 \\
\hline Outlet air & ${ }^{\circ} \mathrm{C}$ & - & 49.58 & 41.15 & 35.54 \\
\hline $\begin{array}{c}\text { Logarithmic mean } \\
\text { temperature difference }\end{array}$ & ${ }^{\circ} \mathrm{C}$ & 39.44 & 12,895 & 15,061 & 29,576 \\
\hline Area of heat exchangers & $\mathrm{m}^{2}$ & 30,847 & & & 60 \\
\hline
\end{tabular}


Figure 5 presents the heat transfer curve of the improved WHUS. As indicated both in this figure and in Table 3, the improved WHUS fully realizes the energy grade match among the exhaust flue gas, air and the condensed water. By adopting two additional heat exchangers, the seventh-stage steam extraction and low-temperature flue gas are utilized to heat the air before it enters the main air preheater, which guarantee the logarithmic mean temperature difference of the air preheating process can be controlled within $36^{\circ} \mathrm{C}$. Subsequently, approximately one-third of the flue gas cooled from $372{ }^{\circ} \mathrm{C}$ down to $131^{\circ} \mathrm{C}$ is saved and introduced into the bypass flue gas duct to heat the feedwater and the condensed water. Part of the first, second, third, fifth and sixth-stage steam extractions could be saved and continued to expand for more power output in the steam turbine. Evidently, the energy saving effects of the improved WHUS are enhanced remarkably.

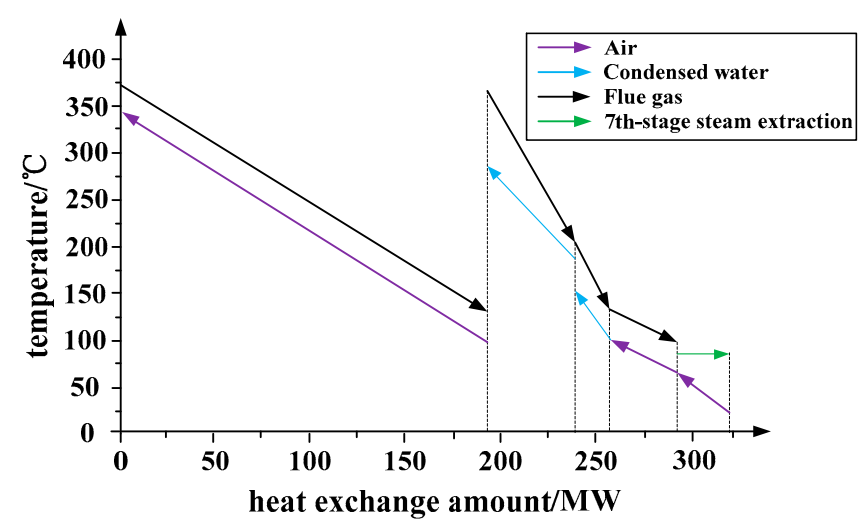

Figure 5. Heat transfer curve of the improved WHUS.

\subsection{Thermodynamic Performance Results}

The thermodynamic analysis comparison between the conventional WHUS (as shown in Figure 2) and the improved WHUS (as presented in Figure 4) is shown in Table 4. The gross work output of the improved WHUS increases by $22.01 \mathrm{MW}$. This increase is mainly because the temperature of the flue gas used to heat the feedwater and the condensed water is from $372{ }^{\circ} \mathrm{C}$ down to $131^{\circ} \mathrm{C}$ in the improved WHUS, which is much higher than that of the conventional WHUS $\left(100-131^{\circ} \mathrm{C}\right)$. The high-grade steam extraction can thus be replaced. As a result, gross work output improves significantly.

However, since several additional heat exchangers are adopted in the improved WHUS, some pumps and fans are required to overcome the resistance of the water, air and flue gas. As indicated in Table 4, the auxiliary power in the improved WHUS increases by $2.28 \mathrm{MW}$. Overall, the increment in the net power output is $19.51 \mathrm{MW}$ in the improved WHUS, and the reduction in heat consumption rate is $143.35 \mathrm{~kJ} / \mathrm{kWh}$; whereas for the conventional WHUS, the aforementioned performance parameters are only $5.83 \mathrm{MW}$ and $42.56 \mathrm{~kJ} / \mathrm{kWh}$, respectively. Thus, the thermal efficiency of the improved WHUS is significantly improved. 
Table 4. Component sizing for the conventional WHUS and improved WHUS.

\begin{tabular}{cccc}
\hline Item & Unit & Conventional WHUS & Improved WHUS \\
\hline High-temperature gas-water heat exchanger & MW & - & 46.13 \\
Low-temperature gas-water heat exchanger & MW & - & 19.59 \\
Second-stage heat exchanger & MW & - & 34.87 \\
First-stage heat exchanger & MW & - & 30.85 \\
Low-temperature economizer & MW & 34.87 & - \\
Auxiliary power increment & MW & 1.25 & 2.28 \\
Gross work output & MW & 1007.15 & 1022.01 \\
Additional gross work output & MW & 7.15 & 22.01 \\
Net work output & MW & 947.83 & 961.51 \\
Additional net power output & MW & 5.83 & 19.51 \\
Reduction in heat rate & $\mathrm{kJ} / \mathrm{kWh}$ & 42.56 & 143.35 \\
\hline
\end{tabular}

\subsection{Variation in the Steam Extraction and Work Output}

Figure 6 shows the effects of waste heat utilization on the steam extraction and the work output of different systems. The column chart with a slash line represents the variation in the multistage steam extractions of the regenerative heaters. When the steam extraction is reduced, the column is located above the $x$ axis; conversely, the column is located below the $x$ axis if steam extraction is increased. The shaded column denotes the variation in work, if there is an increment in work, the column is located above the $x$ axis, and vice versa. The following conclusions can be drawn from Figure 6 :

1. In the conventional WHUS, by adopting the LTE, the flue gas with temperatures of $100-131{ }^{\circ} \mathrm{C}$ is utilized to heat the condensed water from the inlet of the RH6, as a consequence of which, the sixth-stage steam extraction has a saving of $14.06 \mathrm{~kg} / \mathrm{s}$ and the power output is increased by 7.37 MW. Meanwhile, it has to be noted that the seventh and eighth-stage steam extractions show a slight increase. This can be mainly attributed to the fact that the reduction in the sixth-stage steam extraction limits the drainage water flowing into RH7 and RH8 accordingly. However, considering the variation in the seventh and eighth-stage steam extractions is relatively small, the resultant power output variation can almost be neglected. In summary, the total steam extraction of the conventional WHUS decreases by $13.12 \mathrm{~kg} / \mathrm{s}$ whereas the power output increases by $7.15 \mathrm{MW}$.

2. In the improved WHUS, there are obvious changes in the first, second, third, fifth and sixth-stage steam extractions. The reason is that the gas-water heat exchangers arranged in the bypass flue gas duct utilize part of the flue gas cooled from $372{ }^{\circ} \mathrm{C}$ down to $131^{\circ} \mathrm{C}$ to heat the feedwater of RH1-RH3 and the condensed water of RH5-RH6. As a result, the steam extractions of these regenerative heaters reduce considerably. The seventh-stage steam extraction is increased by $13.72 \mathrm{~kg} / \mathrm{s}$, which is utilized to preheat the air in the first-stage heat exchanger. Besides, the steam extraction of DEA is increased whereas the eighth-stage steam extraction is reduced; this is because the drainage water flowing into DEA and RH8 is affected by the steam extraction of the prior stage regenerative heater, which will further affect the steam extraction of DEA and RH8. Overall, in the improved WHUS, the total reduction of steam extraction is $11.87 \mathrm{~kg} / \mathrm{s}$ whereas the power output increases by $22.01 \mathrm{MW}$.

3. In the heat regenerative system, there is a huge working ability difference between the steam extractions from different stages of regenerative heaters. For instance, the working abilities of the first, second, third, fifth and sixth-stage steam extractions are obviously higher than that of the seventh-stage steam extraction. As can be seen from Figure 6, by saving $1 \mathrm{~kg}$ steam extraction of RH1, RH2 and RH3, the corresponding additional power outputs are 1.21 MW, 1.15 MW, and $0.94 \mathrm{MW}$, respectively. Whereas saving $1 \mathrm{~kg}$, sixth-stage steam extraction can only improve the power output by $0.45 \mathrm{MW}$; as for RH7, the power output is only decreased by $0.25 \mathrm{MW}$ if the steam extraction consumption is increased by $1 \mathrm{~kg}$. 
4. The overall reductions in the steam extractions of the conventional WHUS and improved WHUS varied slightly $(13.12 \mathrm{~kg} / \mathrm{s}$ vs. $11.87 \mathrm{~kg} / \mathrm{s})$. Furthermore, the exhaust flue gas temperature of these two systems is equally set to $100{ }^{\circ} \mathrm{C}$, which means the same amount of waste heat is recovered. Nevertheless, in the conventional WHUS, the flue gas waste heat is used to save the sixth-stage steam extraction, and the results show that its gross work output increment is 7.15 MW. However, the first, second, third, fifth and sixth-stage steam extractions are significantly reduced in the improved WHUS despite the increase in the seventh-stage steam extraction. Finally, the gross work output increment reaches $22.01 \mathrm{MW}$, which is approximately three times that of the conventional WHUS. In conclusion, with the reasonable utilization of the low-grade energy from both the boiler island and the turbine island, more high-grade steam extraction is saved in the improved WHUS, and better thermodynamic and waste heat recycling performances can be obtained, given that the same amount of waste heat is recovered in the two systems.

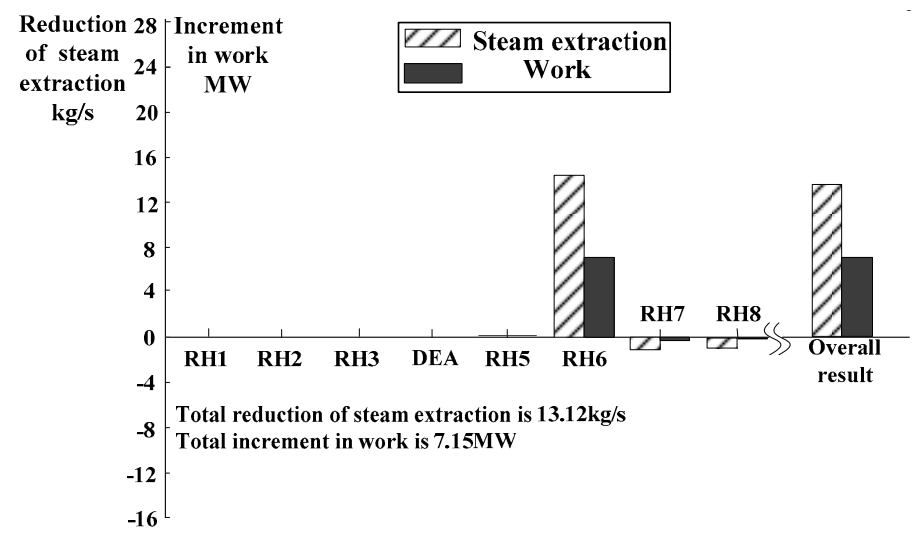

(a) The conventional system

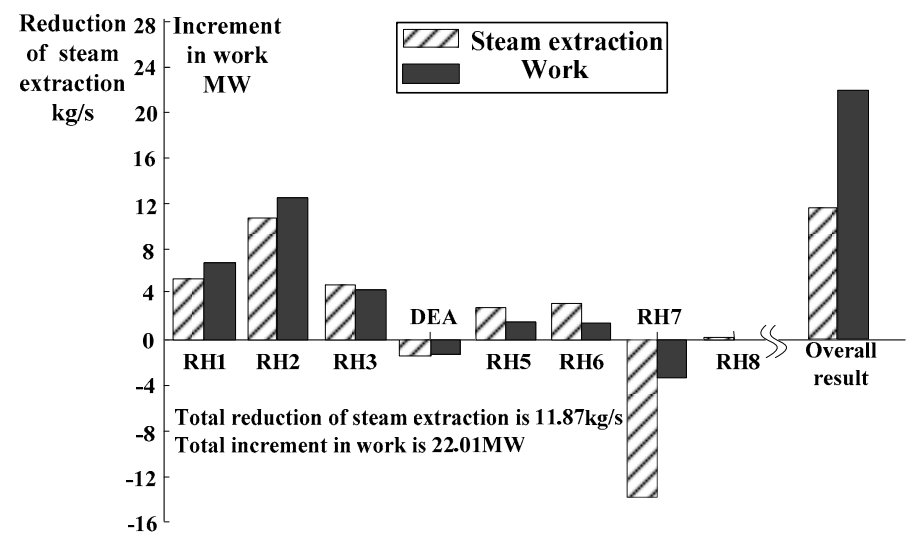

(b) The improved system

Figure 6. Effects of waste heat utilization on the steam turbine regenerative heaters. (a) The conventional WHUS; (b) The improved WHUS.

\section{Exergy Analysis}

To show the internal phenomena of the improved WHUS [22-25], an exergy analysis $[7,8,11,12]$ is performed in this section for both the improved WHUS and the conventional WHUS. The results are listed in Table 5. 
Table 5. Exergy analysis of the conventional WHUS and improved WHUS.

\begin{tabular}{|c|c|c|c|c|}
\hline \multirow{2}{*}{$\begin{array}{c}\text { Items } \\
\text { Unit }\end{array}$} & \multicolumn{2}{|c|}{ Conventional WHUS } & \multicolumn{2}{|c|}{ Improved WHUS } \\
\hline & MW & $\%$ & MW & $\%$ \\
\hline $\begin{array}{l}\text { Exergy input } \\
\text { Fuel input } \\
\text { Exergy output }\end{array}$ & 2248.06 & $100.00 \%$ & 2248.06 & $100.00 \%$ \\
\hline Gross power output & 1007.15 & $44.80 \%$ & 1022.01 & $45.46 \%$ \\
\hline $\begin{array}{c}\text { Exergy destruction } \\
\text { exhaust flue gas } \\
\text { Boiler island }\end{array}$ & 156.48 & $6.96 \%$ & 156.48 & $6.96 \%$ \\
\hline Air preheater & 26.80 & $1.19 \%$ & 5.86 & $0.26 \%$ \\
\hline Bypass flue gas duct & - & - & 4.39 & $0.20 \%$ \\
\hline Low-temperature economizer & 0.86 & $0.04 \%$ & - & - \\
\hline Second-stage heat exchanger & - & - & 3.05 & $0.14 \%$ \\
\hline First-stage heat exchanger & - & - & 3.46 & $0.15 \%$ \\
\hline Other equipment & 915.92 & $40.74 \%$ & 915.92 & $40.74 \%$ \\
\hline \multicolumn{4}{|l|}{ Turbine island } & $41.49 \%$ \\
\hline Cylinder stator & 66.35 & $2.95 \%$ & 66.83 & $2.97 \%$ \\
\hline Condenser & 36.38 & $1.62 \%$ & 36.37 & $1.62 \%$ \\
\hline Regenerative system & 26.09 & $1.16 \%$ & 22.12 & $0.98 \%$ \\
\hline Other equipment & 12.03 & $0.54 \%$ & 11.57 & $0.52 \%$ \\
\hline Total exergy destruction in the turbine island & 140.85 & $6.27 \%$ & 136.89 & $6.09 \%$ \\
\hline Exergy efficiency $(\%)$ & \multicolumn{2}{|c|}{$44.80 \%$} & \multicolumn{2}{|c|}{$45.46 \%$} \\
\hline
\end{tabular}

As shown in Table 5, the exergy efficiency of the improved WHUS is $45.46 \%$, which is $0.66 \%$ higher than that of the conventional WHUS. Comparing the exergy distribution of the improved WHUS with the conventional WHUS, it can be found that the exergy destruction of the improved WHUS is reduced by 10.9 MW in the boiler island and 3.96 MW in the turbine island. Hence, the reduced exergy destruction of the improved WHUS is mainly attributed to the boiler island.

To be specific, the exergy destruction in the boiler island is significantly affected by the air preheating process. This influence is ascribed to the fact that the improved WHUS utilizes low-pressure steam extraction and low-temperature flue gas to heat the air in sequence. Therefore, the heat transfer temperature difference decreases significantly in the air preheating process. As a result, the heat transfer exergy destruction decreases by $14.43 \mathrm{MW}$. However, by adopting the bypass flue gas duct, the exergy destruction in the boiler island increases by 4.39 MW. By taking the exergy destruction of other parts in the boiler island into account, the exergy destruction in the boiler island of the improved WHUS is reduced by 10.9 MW compared to that of the conventional WHUS.

As for the turbine island, the variation in exergy destruction mainly takes place in the regenerative process. The reason accounting for this is that, in the improved WHUS, more feedwater and condensed water is heated via the gas-water heat exchangers adopted in the bypass flue gas duct in the boiler island; thereby the water volume flowing through the regenerative system is reduced significantly, and the exergy destruction is reduced by 3.97 MW accordingly. Besides, with consideration of the exergy destruction in other parts such as the condenser and pipeline, etc., the total exergy destruction in the turbine island of the improved WHUS is reduced by $3.96 \mathrm{MW}$, compared to that of the conventional WHUS.

From the analysis above, it is obvious that the improved WHUS utilizes the low temperature energy in both the boiler island and the turbine island reasonably well, thereby realizing the energy grade improvement of the waste heat utilization process. Essentially, the exhaust flue gas temperature of the improved WHUS stays the same as that of the conventional WHUS, but the exergy destruction of the air preheating is significantly reduced. Finally, the exergy efficiency of the improved WHUS is improved by $0.66 \%$, which seems very small numerically, noting that the denominator of efficiency calculation is extremely large (2248.06 MW); thereby the resultant energy-saving effects are actually 
rather considerable. As presented in Table 4, given the same fuel input, the additional power output of the improved WHUS is $19.51 \mathrm{MW}$, achieving more than three times the conventional WHUS (5.83 MW), reflecting the remarkable energy-saving benefits of the improved WHUS.

\section{Techno-Economic Analysis}

To further evaluate the energy-saving benefits of the improved WHUS in actual engineering application, a techno-economic analysis is conducted in this section. The following assumptions are adopted for the analysis: (1) the on-grid power tariff is set at $0.061 \mathrm{USD} / \mathrm{kWh}$; (2) the annual operation hours of the power generation unit is 5000 hours [26]. Here, the annual operation hours stand for the equivalent operation hours of the power generation unit under the rated capacity. Hence, for the power unit that operates below the rated capacity constantly, its annual operation hours are relatively low in spite of the high actual operation hours. Considering that nowadays it is very common for large-scale coal-fired power units in China to participate in peak load regulation, which means that they are operated below the rated capacity in the long term, the annual operation hours of the coal-fired power units in China are comparatively low; (3) the operation and maintenance (O\&M) cost accounts for 4\% of the total investment annually $[27,28]$; and (4) the exchange rate is set at $6.25 \mathrm{CNY} / \mathrm{USD}$.

\subsection{Estimation of the Total Investment Cost}

Based on the scaling up method $[5,29,30]$, the investment of the new added equipment and the related pump are estimated by the following equation:

$$
T I C=G D P(C E) \times I_{\text {install }, \mathrm{b}} \times\left(\frac{\text { Size }_{\mathrm{a}}}{\text { Size }_{\mathrm{b}}}\right)^{f} \times K
$$

where TIC is the total investment cost of system optimization; $I_{\text {Install, } b}$ is the investment cost for the benchmark equipment; $S_{i z e_{\mathrm{a}}}$ and $S_{i z e_{\mathrm{b}}}$ are the size parameters of the equipment and the benchmark equipment, respectively; $f$ is the size factor; $G D P$ is the variation factor; $C E$ is the price index factor for the chemical equipment; $K$ is the region factor. The detailed reference data is listed in Table 6.

Table 6. Reference data for components in both systems.

\begin{tabular}{ccccccccc}
\hline Component & Scaling Parameter & $\mathbf{I}_{\text {Install, } \mathbf{b}}(\mathbf{M S})$ & $\mathbf{S i z e}_{\mathbf{b}}$ & $\mathbf{f}^{\mathbf{e}}$ & $\mathbf{G D P}^{\mathbf{d}}$ & $\mathbf{C E}^{\mathbf{d}}$ & $\mathbf{K}^{\mathbf{d}}$ & Notes \\
\hline Air preheater & Area & 3.82 & $3.395 \times 10^{5} \mathrm{~m}^{2}$ & 0.67 & 1 & 1 & 1 & $\mathrm{a}$ \\
Heater & Area & 0.693 & $1.315 \times 10^{2} \mathrm{~m}^{2}$ & 0.67 & 1 & 1 & 1 & $\mathrm{~b}$ \\
Pump & Outlet pressure & 0.093 & $80 \mathrm{bar}$ & 0.67 & 1 & 1 & 1 & $\mathrm{c}$ \\
\hline
\end{tabular}

a: Cost is estimated using data from China Electric Power Planning and Design Institute [31]. b: Cost is taken from a feasibility study of flue gas waste heat recovery project in China 2009 [32]. c: Cost is quoted from Moaseri [33].

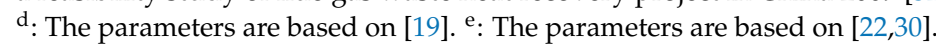

The specific investment costs for the added components of the improved WHUS are listed in Table 7, with the reference capital investment costs of components being the same as those of the conventional WHUS and the costs for pipeline and engineering installation estimated to be $5 \%$ and $17 \%$ of the total equipment investment cost [34], respectively. For the conventional WHUS, introducing the LTE adds USD 2.993 million to the original total investment; with consideration of other investments such as pumps, pipeline, construction and installation, its TIC is USD 3.765 million. While for the improved WHUS, as the logarithmic heat transfer temperature difference of the air preheater decreases because of the increasing inlet air temperature, its heat transfer area and investment cost will be increased, thus an extra USD 0.632 million is required for the air preheater, as shown in Table 7. Moreover, the gas-water heat exchangers and two-stage heat exchangers introduce additional capital costs of USD 1.911 million and USD 4.175 million, respectively. Taking other relevant investments into account, the TIC of the improved WHUS achieves USD 8.536 million. 
Table 7. Investment cost of the added equipment.

\begin{tabular}{clcc}
\hline Item & Unit & Conventional WHUS & Improved WHUS \\
\hline Air preheater & million USD & - & 0.632 \\
High-temperature gas-water heat exchanger & million USD & - & 1.227 \\
Low-temperature gas-water heat exchanger & million USD & - & 0.684 \\
Second-stage heat exchanger & million USD & - & 3.416 \\
First-stage heat exchanger & million USD & - & 0.759 \\
Low-temperature economizer & million USD & 2.993 & - \\
Pumps & million USD & 0.093 & 0.279 \\
Pipeline & million USD & 0.154 & 0.35 \\
Engineering cost of installation & million USD & 0.525 & 1.189 \\
Total investment cost & million USD & 3.765 & 8.536 \\
\hline
\end{tabular}

\subsection{Economic Performance Index}

Based on the investment estimation results, this section analyzes the feasibility of the improved WHUS from the perspective of economic benefits. The net annual revenue (NAR) is calculated based on the dynamic analysis, the construction investment and the operation cost estimation. The specific formula is as follows:

$$
N A R=E A I-C_{\mathrm{TIC}}^{\prime}-C_{\mathrm{O} \& \mathrm{M}}
$$

where $E A I$ is the additional income per year generated by the system optimization, which is calculated as:

$$
E A I=\Delta P_{\text {net }} h_{\mathrm{eq}} C_{\mathrm{e}}
$$

where $h_{\mathrm{eq}}$ is the equivalent operation hours per year and $C_{\mathrm{e}}$ is the on-grid power tariff.

In addition, the annualized investment $\operatorname{cost}\left(C_{\text {TIC }}^{\prime}\right)$ can be calculated as follows [26,35]:

$$
C_{\mathrm{TIC}}^{\prime}=\operatorname{TIC}^{\prime} \frac{i(1+i)^{n}}{(1+i)^{n}-1}
$$

where $i$ refers to the fraction interest rate per year, which is set at $8 \%$; and $n$ represents the system lifespan, which is presumably 20 years, $T I C^{\prime}$ represents the total investment cost (million USD).

$$
T I C^{\prime}=T I C+T I C_{\text {pipe }}+T I C_{\text {install }}
$$

where TIC, $T I C_{\text {pipe, }}$ and $T I C_{\text {install }}$ represent the investment of the new added equipment, the cost of pipes and the engineering installation cost (USD million), respectively.

Table 8 provides the techno-economic analysis results. The EAI of the improved WHUS is almost USD 5.951 million, which is more than three times the EAI of the conventional WHUS. The $\mathrm{C}_{\text {TIC }}$ and CO\&M of the improved WHUS are larger than that of the conventional WHUS, achieving USD 0.869 million and USD 0.341 million, respectively. Nevertheless, the net additional power output in the improved WHUS is much higher than that in the conventional WHUS and it will majorly affect the NAR. Consequently, the NAR of the improved WHUS is USD 4.741 million per year, which shows its excellent economic performance.

Table 8. Results of techno-economic analysis.

\begin{tabular}{cccc}
\hline Item & Unit & Conventional WHUS & Improved WHUS \\
\hline Net additional power output & MW & 5.83 & 19.51 \\
Extra annual income(EAI) & million USD & 1.778 & 5.951 \\
Annualized investment capital cost $\left(\mathrm{C}_{\mathrm{TIC}}\right)$ & million USD & 0.383 & 0.869 \\
Operation \& maintenance cost $\left(\mathrm{C}_{\mathrm{O}}\right.$ M & million USD & 0.151 & 0.341 \\
Net annual revenue(NAR) & million USD & 1.244 & 4.741 \\
\hline
\end{tabular}




\section{Conclusions}

In this study, an improved low-temperature flue gas waste heat utilization system is proposed based on the energy cascade utilization principles. In-depth analyses on the thermodynamic and techno-economic characteristics of the improved WHUS were conducted. The following conclusions can be drawn:

1. In the conventional WHUS, in order to recycle the flue gas waste heat, the LTE is adopted and arranged downstream of the air preheater in the flue gas duct. The inlet flue gas temperature of the LTE is $131{ }^{\circ} \mathrm{C}$, which can replace part of the sixth-stage steam extraction. Combined with the engineering constraints, the heat rate of the power generation unit is only reduced by $42.56 \mathrm{~kJ} /(\mathrm{kWh})$. Furthermore, the energy-saving effects are limited.

2. In the improved WHUS, the low-temperature heat from both the boiler island and the turbine island is utilized to preheat the air. In this way, the inlet air temperature of the air preheater is increased, and additionally, the saved high temperature flue gas (cooled down from 372 to $131^{\circ} \mathrm{C}$ ) can be introduced to the bypass flue gas duct to heat the feedwater and the condensed water. Consequently, part of the high-pressure steam extraction is saved, leading to the net power output of the improved WHUS increasing by $19.51 \mathrm{MW}$, while the heat rate is reduced by $143.35 \mathrm{~kJ} /(\mathrm{kWh})$. The energy-saving effects of the improved WHUS are remarkable.

3. In the conventional WHUS, the sixth-stage steam extraction is saved, while in the improved WHUS, the first, second, third, fifth and sixth-stage steam extractions are saved. In general, the working ability of the high-pressure steam extraction is much greater than that of the low-pressure steam extraction. Therefore, the resultant energy-saving effects differ distinctly although the total amounts of steam saved by both systems are almost similar.

4. For the conventional WHUS, the logarithmic mean temperature difference in the air preheating process reaches $60{ }^{\circ} \mathrm{C}$. However, in the improved WHUS, the logarithmic mean temperature difference is less than $36^{\circ} \mathrm{C}$ because the air is successively heated by low-pressure steam extraction and low-temperature flue gas. In this case, the exergy destruction of the air preheating process is reduced by $14.43 \mathrm{MW}$, which is the main reason for the decrease in the total exergy destruction of the improved WHUS. Ultimately, the exergy efficiency of the improved WHUS improves to $45.46 \%$.

5. Techno-economic analysis results show that the total investment of the improved WHUS is USD 8.536 million, which is double when compared to that of the conventional WHUS. However, the net additional power output in the improved WHUS is $19.51 \mathrm{MW}$, which is over three times that of the conventional WHUS. Consequently, the net annual revenue of the improved WHUS is up to USD 4.741 million per year, which is approximately four times that of the conventional WHUS.

Acknowledgments: This study was supported by the National Major Fundamental Research Program of China No. (2011CB710706), the National Nature Science Fund of China (No. 51025624), the 111 Project (B12034), the Fundamental Research Funds for the Central Universities (No. 2014ZD04).

Author Contributions: Shengwei Huang and Yongping Yang conceived and designed the improved WHUS; Shengwei Huang and Chengzhou Li conducted the analysis of the energy-saving characteristics of the improved WHUS and the conventional WHUS; Tianyu Tan and Peng Fu wrote the paper; Gang Xu contributed analysis tools. Shengwei Huang contributed the main jobs to the work reported.

Conflicts of Interest: The authors declare no conflict of interest. 


\section{Abbreviations}

$\begin{array}{ll}\text { WHUS } & \text { Waste heat recovery system } \\ \text { RH } & \text { Regenerative heater } \\ \text { LTEs } & \text { Low-temperature economizers } \\ \text { THA } & \text { The design condition } \\ \text { HPT } & \text { High-pressure turbine } \\ \text { IPT } & \text { Intermediate-pressure turbine } \\ \text { LPT } & \text { Low-pressure turbine } \\ \text { NAR } & \text { The net annual revenue } \\ \text { O\&M } & \text { Operation and maintenance }\end{array}$

\section{Symbols}

\begin{tabular}{|c|c|}
\hline$m_{\mathrm{w}, \text { out }}$ & Outlet mass flow of water, $\mathrm{kg} / \mathrm{s}$ \\
\hline$h_{\mathrm{w}, \text { out }}$ & Outlet enthalpy of water, $\mathrm{kJ} / \mathrm{kg}$ \\
\hline$m_{\mathrm{w}, \text { in }}$ & Inlet mass flow of water, $\mathrm{kg} / \mathrm{s}$ \\
\hline$h_{\mathrm{w}, \text { in }}$ & Inlet enthalpy of water, $\mathrm{kJ} / \mathrm{kg}$ \\
\hline$m_{\mathrm{d}, \text { in }}$ & Inlet mass flow of drainage, $\mathrm{kg} / \mathrm{s}$ \\
\hline$h_{\mathrm{d} \text {,in }}$ & Inlet enthalpy of drainage, $\mathrm{kJ} / \mathrm{kg}$ \\
\hline$m_{\mathrm{d}, \text { out }}$ & Outlet mass flow of drainage, $\mathrm{kg} / \mathrm{s}$ \\
\hline$h_{\mathrm{d}, \text { out }}$ & Outlet enthalpy of drainage, $\mathrm{kJ} / \mathrm{kg}$ \\
\hline$h_{\mathrm{g}, \text { in }}$ & Inlet enthalpy of fuel gas, kJ/kg \\
\hline$h_{\mathrm{g} \text {,out }}$ & Outlet enthalpy of fuel gas, $\mathrm{kJ} / \mathrm{kg}$ \\
\hline$\dot{Q}_{1}$ & Recovered heat, $\mathrm{kW}$ \\
\hline$\Delta m$ & amount of suppressed steam extraction, $\mathrm{t} / \mathrm{h}$ \\
\hline$\Delta P$ & Additional work output, MW \\
\hline$\Delta P_{\mathrm{f}}$ & Increase in auxiliary devices power, MW \\
\hline$D$ & Volume flow of fuel gas, $\mathrm{m}^{3} / \mathrm{s}$ \\
\hline$\Delta P_{\mathrm{r}}$ & Increase in flue gas resistance, $\mathrm{kPa}$ \\
\hline$\eta_{f}$ & Induced draft fan efficiency, $\%$ \\
\hline$\Delta q$ & Reduction of plant heat rate, $\mathrm{kJ} / \mathrm{kWh}$ \\
\hline$P_{\text {net }}$ & Net electricity output, MW \\
\hline$\Delta P_{\text {net }}$ & Net additional power output, MW \\
\hline TIC & Total investment capital, million USD \\
\hline EAI & Extra annual income, million USD \\
\hline Size & The size parameters of equipment \\
\hline $\mathrm{CE}$ & Price index factor \\
\hline K & Region factor \\
\hline$f$ & Size factor \\
\hline$I_{\text {install }}$ & Investment cost for benchmark equipment, Million USD \\
\hline$h_{\mathrm{eq}}$ & The equivalent operation per year, h/year \\
\hline$C_{e}$ & On-grid power tariff, USD/kWh \\
\hline$i$ & Fraction interest rate per year, $\%$ \\
\hline$n$ & Number of years \\
\hline
\end{tabular}

\section{References}

1. Yuan, J.H.; Na, C.N.; Lei, Q.; Xiong, M.P.; Guo, J.S.; Hu, Z. Coal use for power generation in China. Resour. Conserv. Recy. 2016. [CrossRef]

2. $\mathrm{Gu}, \mathrm{Y} . J . ; \mathrm{Xu}, \mathrm{J} . ;$ Chen, D.C.; Wang, Z.; Li, Q.Q. Overall review of peak shaving for coal-fired power units in China. Renew. Sust. Energ. Rev. 2016, 54, 723-731. [CrossRef]

3. Yang, Y.P.; Yang, Z.P.; Xu, G.; Wang, N.N. Situation and prospect of energy consumption for China's thermal power generation. Proc. Chin. Soc. Electric. Eng. 2013, 33, 1-11. (In Chinese)

4. Department of Energy Statistics. China Energy Statistical Yearbook 2011; China Statistics Press: Beijing, China, 2011. (In Chinese) 
5. Sueyoshi, T.; Goto, M.; Ueno, T. Performance analysis of US coal-fired power plants by measuring three DEA efficiencies. Energy Policy 2010, 38, 1675-1688. [CrossRef]

6. Beér, J.M. High efficiency electric power generation: The environmental role. Prog. Energy Combust. Sci. 2007, 33, 107-134. [CrossRef]

7. Wang, L.; Yang, Y.; Dong, C.; Yang, Z.; Xu, G.; Wu, L. Exergoeconomic Evaluation of a Modern Ultra-Supercritical Power Plant. Energies 2012, 5, 3381-3397. [CrossRef]

8. Wang, L. Thermo-economic evaluation, optimization and synthesis of large-scale coal-fired power plants. Ph.D. Thesis, Technische Universität, Berlin, Germany, 25 August 2016.

9. Fu, P.; Wang, N.; Wang, L.; Morosuk, T.; Yang, Y.; Tsatsaronis, G. Performance degradation diagnosis of thermal power plants: A method based on advanced exergy analysis. Energy Convers. Manage. 2016, 130, 219-229. [CrossRef]

10. Wang, L.; Fu, P.; Wang, N.; Morosuk, T.; Yang, Y.; Tsatsaronis, G. Malfunction diagnosis of thermal power plants based on advanced exergy analysis: The case with multiple malfunctions occurring simultaneously. Energy Convers. Manage. 2017, 148, 1453-1467. [CrossRef]

11. Wang, L.; Yang, Y.; Morosuk, T.; Tsatsaronis, G. Advanced Thermodynamic Analysis and Evaluation of a Supercritical Power Plant. Energies 2012, 5, 1850-1863. [CrossRef]

12. Yang, Y.; Wang, L.; Dong, C.; Xu, G.; Morosuk, T.; Tsatsaronis, G. Comprehensive exergy-based evaluation and parametric study of a coal-fired ultra-supercritical power plant. Appl. Energy 2013, 112, 1087-1099. [CrossRef]

13. Wang, L.; Wu, L.; Xu, G.; Dong, C.; Yang, Y. Calculation and analysis of energy consumption interactions in thermal systems of large-scale coal-fired steam power generation units. Proc. Chin. Soc. Electric. Eng. 2012, 32, 9-14. (In Chinese)

14. Wang, L.; Yang, Y.; Dong, C.; Xu, G. Improvement and primary application of theory of fuel specific consumption. Proc. Chin. Soc. Electric. Eng. 2012, 32, 16-21. (In Chinese)

15. Wang, L.; Yang, Y.; Dong, C.; Morosuk, T.; Tsatsaronis, G. Systematic Optimization of the Design of Steam Cycles Using MINLP and Differential Evolution. ASME J. Energy Resour. Technol. 2014, 136, 031601. [CrossRef]

16. Wang, L.; Yang, Y.; Dong, C.; Morozuk, T.; Tsatsaronis, G. Parametric optimization of supercritical coal-fired power plants by MINLP and differential evolution. Energy Convers. Manage. 2014, 85, 828-838. [CrossRef]

17. Wang, L.; Voll, P.; Lampe, M.; Yang, Y.; Bardow, A. Superstructure-free synthesis and optimization of thermal power plants. Energy 2015, 91, 700-711. [CrossRef]

18. Wang, L.; Lampe, M.; Voll, P.; Yang, Y.; Bardow, A. Multi-objective superstructure-free synthesis and optimization of thermal power plants. Energy 2016, 116, 1104-1116. [CrossRef]

19. Han, X.; Yan, J.; Karellas, S.; Liu, M.; Kakaras, E.; Xiao, F. Water extraction from high moisture lignite by means of efficient integration of waste heat and water recovery technologies with flue gas pre-drying system. Appl. Therm. Eng. 2017, 110, 442-456. [CrossRef]

20. Li, C.; Wang, H. Power cycles for waste heat recovery from medium to high temperature flue gas sources-From a view of thermodynamic optimization. Appl. Energy 2016, 180, 707-721. [CrossRef]

21. Wang, C.J.; He, B.S.; Sun, S.Y.; Wu, Y.; Yan, N.; Yan, L.B.; Pei, X.H. Application of a low pressure economizer for waste heat recovery from the exhaust flue gas in a 600 MW power plant. Energy 2012, 48, 196-202. [CrossRef]

22. Wang, C.J.; He, B.S.; Yan, L.B.; Pei, X.H.; Chen, S.N. Thermodynamic analysis of a low-pressure economizer based waste heat recovery system for a coal-fired power plant. Energy 2014, 65, 80-90. [CrossRef]

23. Espatolero, S.; Cortes, C.; Romeo, L.M. Optimization of boiler cold-end and integration with the steam cycle in supercritical units. Appl. Energy 2010, 87, 1651-1660. [CrossRef]

24. Chen, Q.; Finney, K.; Li, H.N.; Zhang, X.H.; Zhou, J.; Sharifi, V.; Swithenbank, J. Condensing boiler applications in the process industry. Appl. Energy 2012, 89, 30-36. [CrossRef]

25. Yang, Y.; Xu, C.; Xu, G.; Han, Y.; Fang, Y.; Zhang, D. A new conceptual cold-end design of boilers for coal-fired power plants with waste heat recovery. Energ. Convers. Manage. 2015, 89, 137-146. [CrossRef]

26. Xu, G.; Xu, C.; Yang, Y.; Fang, Y.; Li, Y.; Song, X. A novel flue gas waste heat recovery system for coal-fired ultra-supercritical power plants. Appl. Therm. Eng. 2014, 67, 240-249. [CrossRef]

27. Wang, D.; Bao, A.; Kunc, W.; Liss, W. Coal power plant flue gas waste heat and water recovery. Appl. Energy 2012, 91, 341-348. [CrossRef] 
28. Strömberg, L.; Lindgren, G.; Jacoby, J.; Giering, R.; Anheden, M.; Burchhardt, U.; Altmann, H.; Kluger, F.; Stamatelopoulos, G.N. Update on Vattenfall's 30 MWth oxyfuel pilot plant in Schwarze Pumpe. Energy Procedia 2009, 1, 581-589.

29. Xu, G.; Huang, S.W.; Yang, Y.P.; Wu, Y.; Zhang, K.; Xu, C. Techno-economic analysis and optimization of the heat recovery of utility boiler flue gas. Appl. Energy 2013, 112, 907-917. [CrossRef]

30. Waigaoqiao: World Class in Clean Coal. Available online: https://www.energy.siemens.com/us/pool/ hq/energy-topics/living-energy/issue-2/LivingEnergy_Issue2_Cleaner_Coal_in_China.pdf (accessed on 17 August 2017).

31. Jin, H.W. Design optimization of $1000 \mathrm{MW}$ ultra supercritical thermal power generating unit. Zhejiang Electr. Power 2012, 7, 38-40. (In Chinese)

32. Long, H.; Yan, S.; Wang, D. Integrated design technology development of ultra-supercritical unit. Electr. Power Constr. 2011, 32, 71-75. (In Chinese)

33. Feng, W.Z. Development of China's supercritical coal fired power generation unit. J. Shanghai Univ. Electr. Power 2011, 27, 417-422. (In Chinese)

34. Hu, Y.P.; Zhu, B. Power Plant Boiler Handbook; China Electric Power Press: Beijing, China, 2005. (In Chinese)

35. Shi, X.J.; Che, D.F.; Agnew, B.; Gao, J.M. An investigation of the performance of compact heat exchanger for latent heat recovery from exhaust flue gases. Int. J. Heat Mass Transf. 2011, 54, 606-615. [CrossRef]

36. Li, Z.C. The analysis of the in-depth utilization of flue gas waste heat in power plant. Wireless Tech. 2013, 6, 84-85. (In Chinese)

37. Jiang, A.Z.; Wang, G.; Shi, S.Y.; Zheng, S.H. Discussion on Calculation Formulae of Boiler's Acid Dew-Point Temperature of Gas. Boiler Tech. 2009, 40, 11-13. (In Chinese)

(C) 2017 by the authors. Licensee MDPI, Basel, Switzerland. This article is an open access article distributed under the terms and conditions of the Creative Commons Attribution (CC BY) license (http:/ / creativecommons.org/licenses/by/4.0/). 